\title{
Publicidade: suas representações, narrativas e temporalidades
}

\author{
Eneus Trindade ${ }^{1}$
}

Clotilde Perez ${ }^{2}$

A primeira edição de 2016 da revista Signos do Consumo dedica-se à reflexão sobre a Publicidade, suas representações e narrativas transmidiáticas que buscam o encontro entre pessoas e marcas nos distintos rituais do consumo midiatizado. Tem como eixo condutor da articulação entre os textos a problematização da publicidade por meio da análise das narrativas e representações em diálogo passado-presente-futuro, manifestado pela valorização da história, memória e explorações estéticas das marcas. O V.8 N.1 tem a colaboração de pesquisadores-autores de onze Universidades distintas no Brasil e no exterior, reiterando a postura plural que sempre marcou nossa editoria. Também inaugura a contribuição de André Peruzzo, aluno do último ano de Publicidade da ECA USP, como novo assistente editorial da Signos do Consumo, para o qual damos as boas-vindas e os votos do melhor desempenho diante dos desafios que se apresentam.

Assim, o primeiro artigo de Henrique Mazetti, professor do Departamento de Comunicação Social da Universidade Federal de Viçosa - MG, intitulado “O estudo de representações publicitárias sob uma perspectiva histórica: desafios e apontamentos metodológicos" tem o objetivo de refletir sobre as opções e os desafios metodológicos envolvidos em pesquisas que se propõem a elaborar análises das representações publicitárias sob a perspectiva histórica. Dá início a sua reflexão por meio da identificação de protocolos metodológicos empregados no estudo da publicidade e também em sua interface com a história, para em seguida, discutir sobre a articulação de métodos quantitativos e qualitativos e suas rentabilidades. Configura-se como uma contribuição

\footnotetext{
${ }^{1}$ Professor Livre Docente do Departamento de Relações Públicas, Propaganda e Turismo da ECA/USP. Docente do PPGCOM/ECA/USP na área de teoria e pesquisa em comunicação e Vice-coordenador do Grupos de Estudos Semióticos em Comunicação, Cultura e Consumo CNPq/ECA/USP. Possui pós-doutorado em Antropologia Visual pela Universidade Aberta de Portugal. Doutor e Mestre em Comunicação pela ECA/USP

2 Professora Livre Docente em Ciências da Comunicação do Departamento de Relações Públicas, Propaganda e Turismo da ECA/USP. Docente do PPGCOM/ECA/USP na área de interfaces sociais da comunicação. Coordenadora dos Grupos de Estudos Semióticos em Comunicação, Cultura e Consumo CNPq/ECA/USP. Possui pós-doutorado em Comunicação pela Universidade de Murcia-Espanha. Doutora em Comunicação e Semiótica pela PUC-SP, Mestre em Administração pela PUC-SP.
} 
Publicidade: suas representações, narrativas e temporalidades

de Eneus Trindade e Clotilde Perez

metodológica importante para os estudos das representações publicitárias e do uso de multimétodos na pesquisa em publicidade.

"Onde vivem os objetos: a composição mágico-totêmica da narrativa publicitária na campanha "A revolução na sua garagem" da marca Honda" é o artigo apresentado pelos pesquisadores Hertz Wendel de Camargo, professor adjunto do curso de Publicidade e Propaganda da UFPR e Aryovaldo de Castro Azevedo Junior, professor adjunto do Departamento de Comunicação Social e do PPGCOM da Universidade Federal do Paraná. A partir dos pressupostos dos estudos antropológicos do consumo relacionados às estruturas mágico-totêmicas da narrativa publicitária e das relações míticas entre o homem e o objeto, o texto dá sua contribuição para a interpretação do filme que compõe a campanha 2016 para o carro Honda HR-V, desenvolvida pela agência F/Nazca Saatchi \& Saatchi, cujo mote é "A revolução na sua garagem". Configura-se como caminho metodológico rentável para análise de filmes publicitários no diálogo interdisciplinar entre a Publicidade e a Antropologia.

Javier García López, professor da Universidad a Distância de Madrid e Pedro Hellín Ortuño, professor titular da Universidad de Murcia, Espanha, apresentam o texto "Publicidad interrumpida. Análisis cultural de la comunicación publicitaria en internet". O texto tem como objetivo central a análise do processo da comunicação publicitária na internet, a partir da perspectiva cultural. Por meio do método da argumentação filosófica prática os autores adentram à dissecação do processo de mudança do paradigma publicitário para explicar como as novas linguagens e formatos que se apresentam alteram as lógicas e estratégias publicitárias clássicas.

"Shrek e Bauducco chegam à corte: novas narrativas de crianças como sujeitos de direito e a decisão paradigmática do superior tribunal de justiça brasileiro sobre propaganda dirigida ao público infantil", texto de Paulo Nassar, professor livre-docente da ECAUSP junto PPGCom e ao curso de Relações Públicas e Ana Claudia Pompeu Torezan Andreucci, professora da Universidade Presbiteriana Mackenzie e pós-doutoranda na 
Publicidade: suas representações, narrativas e temporalidades

de Eneus Trindade e Clotilde Perez

ECA - USP, reflete sobre as novas narrativas presentes na decisão judicial do Superior Tribunal de Justiça brasileiro acerca da campanha publicitária dirigida ao público infantil "é hora de Shrek", da marca Bauducco à luz dos princípios protetivos estabelecidos pela Constituição Federal de 1988 e do Estatuto da Criança e do Adolescente. Por meio da análise detalhada da campanha à luz das regulações, os autores trazem destacada contribuição às pesquisas acerca das relações entre Publicidade, Marca e público infantil, com suas tensões, limites e intencionalidades.

Luiz LZ Cesar dos Santos, professor da Universidade Federal do Pará, apresenta o artigo "Publicidade midiática e memórias de elefante". A partir do entendimento da publiCIDADE como um conceito de publicização dos espaços públicos, o texto analisa e discute a campanha publicitária veiculada por meio de cartazes com ilustração antiga de um elefante contendo a frase "A Revolução não será televisionada" espalhados na Avenida Paulista na cidade de São Paulo. Os cartazes servem como peças ilustrativas de mensagens críticas contra a mídia, explorando as relações imagéticas e as memórias do cotidiano expressas nas ruas e avenidas das grandes metrópoles. Traz o diálogo entre memória, publicidade e metrópole contemporânea de forma inovadora.

"A cultura da memória e suas interfaces com a comunicação e o consumo: um estudo sobre a marca Granado", de Mayara Luma Assmar Correia Maia Lobato, professora da FIAM-FAAM de São Paulo e doutoranda do Programa de Pós-Graduação em Comunicação e Práticas de Consumo da Escola Superior de Propaganda e Marketing ESPM, neste artigo apresenta a análise da presença da cultura da memória nas sociedades capitalistas do século XXI, por meio de sua ressonância no universo do consumo especificamente da marca Granado. Por meio das reflexões de Huyssen, Nora, Nunes, Kopytoff e outros, a autora compreende a priorização do estilo retrô na ambientação das lojas, nos rótulos e embalagens e nas fórmulas dos produtos da marca, constatando a valorização estética da memória e seus componentes simbólico-afetivos para a comunicação e a venda de produtos. 
Lívia Silva de Souza doutoranda do PPGCOM - ECA USP, apresenta o artigo "Do consumo de marcação à marcação do consumo: \#Riachuelo e a moda midiatizada". Tomando como fundamento o consumo midiatizado como alicerce das práticas de consumo contemporâneas (Trindade e Perez, 2014), a autora reflete sobre a circulação das marcas nas redes digitais e busca compreender como tais práticas se manifestam de formas singulares, na passagem de uma sociedade do consumo de marcação (Douglas e Isherwood, 2013) para uma sociedade centrada nas pessoas, que não mais passivas, criam sentidos nos seus usos e na marcação de seu consumo. A autora finaliza suas considerações na articulação da reflexão teórica com o estudo da marca de moda Riachuelo, a partir dos usos da hashtag \#riachuelo na rede social Instagram, comprovando a movimentação das marcas às pessoas.

O último artigo que compõe esta edição intitulado "Semiótica aplicada: campanha publicitária journey, com Angelina Jolie, sob o espectro da teoria peirceana, de Carolina Boari Caraciola, doutora em Comunicação e Semiótica pela Pontifícia Universidade Católica de São Paulo e professora da Faculdade Paulus, apresenta neste texto a análise da campanha publicitária Journey, da marca de luxo Louis Vuitton, estrelada pela atriz Angelina Jolie, sob o prisma da semiótica de extração peirceana. A análise da publicidade, sob o espectro da teoria semiótica, permite explicitar o potencial comunicativo engendrando na campanha, uma vez que as estratégias semióticas utilizadas por uma marca são fatores essenciais à sua constituição como signo, sendo, portanto, de fundamental importância para a compreensão de sua natureza, perfil e potenciais interpretantes emocionais e funcionais.

Integra também esta edição a resenha do livro de C. Campbell "A ética romântica e o espírito do consumismo moderno", feita por Rosana Mauro, doutoranda do PPGCom ECA USP. Traz a síntese crítica das reflexões do autor acerca do consumo moderno como experiência romântica e estética, transitando pelos meandros da imaginação à força da imagem. 
Publicidade: suas representações, narrativas e temporalidades

de Eneus Trindade e Clotilde Perez

Desejamos a todos os leitores da Signos a melhor imersão nesta nova edição.

Abraço,

Eneus Trindade e Clotilde Perez, editores 